V. BOBROVSKIY, D. KOZACHENKO, R. VERNIGORA (Dnipropetrovsk National University of Railway Transport named after Academician V. Lazaryan)

\title{
RESEARCHING OPERATION OF THE RAILWAY STATIONS WITH U ING OF THEIR ERGATIC SIMULATION MODELS
}

Наведено загальну структуру функціональної моделі залізничної станції та методика формалізації технологічних процесів станцій. Розроблена модель може бути використана для оптимізації технічних та технологічних параметрів залізничних станцій, в т.ч. з використанням графоаналітичного підходу.

Ключові слова: залізничні станції, імітаційне моделювання, ергатична модель, графоаналітичний підхід.

Приведена общая структура функциональной модели железнодорожной станции и методика формализации технологических процессов станций. Разработанная модель может быть использована для оптимизации технических и технологических параметров железнодорожных станций, в т.ч. с использованием графоаналитического подхода.

Ключевые слова: железнодорожные станции, имитационное моделирование, эргатическая модель, конечный автомат, графоаналитический подход.

The general scheme of railway station's model and technique of formalizing the technologic processes at stations are described. Designed model can be used for optimization of technical and technological parameters of rail ay stations, including with using the grapho-analitical method.

Key words: railway stations, simulation, ergatic model, finite-state automate, grapho-analitical method.

Railway stations are one of the main elements of the infrastructure of transport network. For their steady operation, stations should have sufficient reserve capacity and processing ability to cope with the peak loads. At the same time, the stations' own expenses should be minimized reducing excessive technical potential. The determination of rational parameters of railway stations is a complex multi-variant and multi-criteria problem. In recent years in relation to the market reforms in the railway transport of Ukraine and other CIS countries, significant changes took place. Changing the range of products of enterprises, sharp increasing the share of private freight cars, introducing the high-speed traffic on the adjacent lines, making the traffic safety requirements be more strict due to aging the infrastructure and rolling stock led to the situation when many mainline and industrial railway stations have shortages in the capacity and processing abilities, even in the conditions of a general reduction in traffic volumes. It should be noted that the design standards specified in the "Instructions" in many cases do not correspond to the real conditions of operation of railway stations. In this context, the solution of design and technological problems need a modern and effective tool for obtaining reliable quantitative and qualitative evaluation of the planned changes in stations' design and operation technology. The simulation of station processes on the basis of modern computer technology can serve as an effective tool for analysis and assessment of functioning the stations, their technical-andtechnological and economic parameters. The use of simulation models for the stations' operational management as well as for the implementation of project activities would allow making rational decisions to reduce stations' own expenses and increase the profits of transportation by rail.

A large number of papers are devoted to the development of methods for simulating the operation of railway stations (e.g., refer to [1-7]). However, the analysis shows that in the current models not enough attention is paid to managing the technologic processes (TP) of stations and evaluating its quality. In addition, the efficiency of functioning a station is largely dependent on the level of operational management by dispatch personnel. At the same time, the existing station models practically do not take into account the management activity of dispatch personnel that does not ensure the adequacy of such models. Besides, the currently used methods for developing simulation models require a significant contribution of time and labour of highly skilled programmers and engineers and, as a result, they are often not available for a wide range of practitioners to solve specific problems. To eliminate these drawbacks, the authors have suggested a concept of stations' ergatic models, in which a person is directly involved into the simulation process and manages the station TP acting as a dispatcher.

(C) Bobrovskiy V., Kozachenko D., R. Vernigora 2013 
In doing so, one of the main requirements to these models is the simplicity and versatility of providing the input data at the expense of complicating the internal organization of the simulation software systems. This approach would automate the synthesis of models making them available to a wide range of engineering and technical staff.

The railway station is a complex system consisting of a number of different elements, which interact closely one to another in the process of operation providing mutual influence. To build the functional station models (FSM), the following generic models are developed:

- model of station trackage ;

- model of station automation system;
- model of station technologic process (STP);

- model of operative station management (OSM);

- information model.

These models are developed as separate modules built using an object-oriented approach. Such an organization allows standardizing the integration process for modules into the general FSM for solving problems of different class. In addition, this approach simplifies the synthesis of models of specific stations enabling one to take into account the characteristics of their technical equipment and operation technologies. The proposed FSM modular structure is shown in Fig. 1.

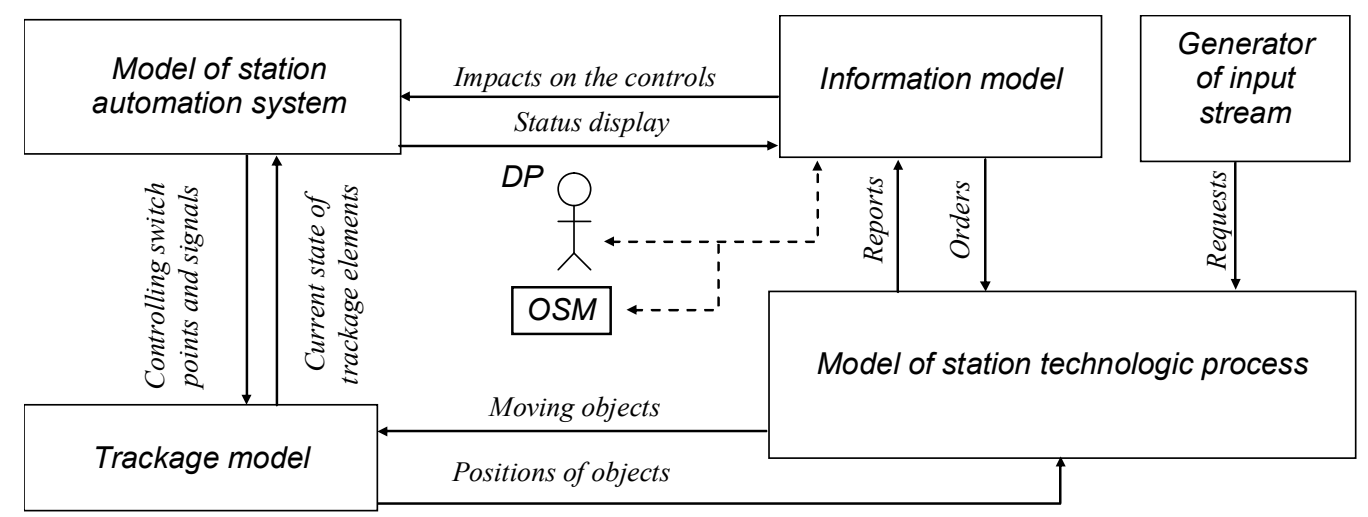

Fig. 1. Structure of functional model of a railway station

Models of trackage of stations and station automation systems are formalized in the form of weighted directed graphs and presented in $[8,9]$. A formal representation of trackage and automation systems in the model of a station allows automating their synthesis, and the availability of data on the actual length of the track sections provides an simulation of train and shunting movements.

One of the main problems arising in the functional simulation of stations is the difficulty of formalizing their technological processes, which may essentially differ at different stations.

In the model developed a station or a separate processing facility is seen as a managed multiphase multichannel queuing system (QS). In the QS the objects, which need maintenance at the station (trains, sets of cars, locomotives etc.), generate the input stream. The individual technologic operations or works (immobilizing of train, technical inspection, breaking up, etc.), which are performed in a specific sequence according to the TP, are service phases. The duration of these operations are to be simulated as random variables, which parameters depend on the characteristics of the object. Executors of technologic operations (car inspectors, shunting locomotives, sorting humps etc.) are serving devices. The service discipline is set by the model's dispatching person (DP) or a system of priorities adopted in the OSM. The structures of data used to represent the objects, executors and works in the TP model (TPM) are presented in [10].The formalization of TP for processing the objects is performed on the basis of deterministic finite-state automaton (FSA) that ensures performing all the complex of technological operations to every object in accordance with their mutual dependence:

$$
A=\left\{X, Z, S, F_{z}, F_{s}\right\},
$$

where $X, Z$ are, respectively, input and output alphabets; $S$ is a set of automatic device states; $F_{z}, F_{s}$ are functions of outputs and transitions.

The input alphabet $X$ of an automaton comprises two subsets of the input signals: $X=\left\{X_{1}\right.$, $\left.X_{2}\right\}$; here $X_{1}$ are external commands from DM or OSM to initiate certain operations to the object; $X_{2}$ are internal signals from the object after termination of each technological operation.

The function $\Psi_{i}$, which is to be performed by FSM at the time of receipt of the input signal $x_{i}$ with the FSA, is assigned to each character $z_{i}$ from the output alphabet $Z$. The functions $\Psi_{i}$ comprise 
command sets of two types $\Psi_{i}=\left\{K_{i 1}, K_{i 2}\right\}$; here $K_{i 1}$ is a list of initialization commands for individual technologic operations with the object; $K_{i 2}$ is a list of commands and messages to be transmitted to structural models of FSM.

Each state of an automaton $s_{q} \in S$ corresponds to a certain state of TP for servicing the objects that is characterized by the completion of each technologic operation $\left(s_{q}=0\right.$ - the operation can not be started, $s_{q}=1-$ the operation can be initiated or executed, $s_{q}=2-$ the operation is completed).

A separate FSA is to be developed to simulate processing the objects of different categories (freight trains, passenger trains, shunting trains, etc.) at the station. The TP of servicing an individual object is simulated by a sequence of FSA transitions from one state to another as the provisional operations are performed. At the beginning of simulation of TP for servicing each object, the corresponding FSA is in the initial state $s_{0}$ (an automaton is initial). Upon completion of all the operations according to the TP, an automaton transits into the final state $s_{f}$, then the corresponding object is to be removed from the QS.

The functions of outputs $F_{z}$ and transitions $F_{s}$ of an automaton $A$ perform the conversion of the in- put signal sequence $\mathbf{x}_{j}=\left\{x_{1}, x_{2}, \ldots x_{\mathrm{K}}\right\}$ into the corresponding output sequence $\mathbf{z}_{j}=\left\{z_{1}, z_{2}, \ldots z_{f}\right\}$. A variety of input sequences $\mathbf{x}_{j}, j=1 \ldots r$, where each one makes the FSA transited from state $s_{0}$ into state $s_{\mathrm{K}}$, is used to formalize the various technology options for servicing an object; the choice of the sequence $\mathbf{x}_{j}$ is to be realized by DP.

An analysis of TP's for servicing various objects at railway stations found that the output and transition tables for the corresponding FSA's are very sparse. In this context, a directed graph is used to represent an automaton. For example, Fig. 2 shows a directed graph of the behavior of automaton simulating the TP for servicing a group of cars in the reception yard; in this process the following technologic operations are to be performed: 1 - moving of a group of cars to an reception yard; 2 - immobilizing by rail skates; 3 - uncoupling a locomotive; 4 - protecting; 5 - technical inspection; 6 - commercial inspection; 7 - coupling a locomotive; 8 - removing rail skates; 9 humping. The DP manages a TP, who for the initialization of individual operations with an object issues the following commands: 101 - "To immobilize", 102 - "To protect", 103 - "To couple a locomotive", 104 - "To humping".

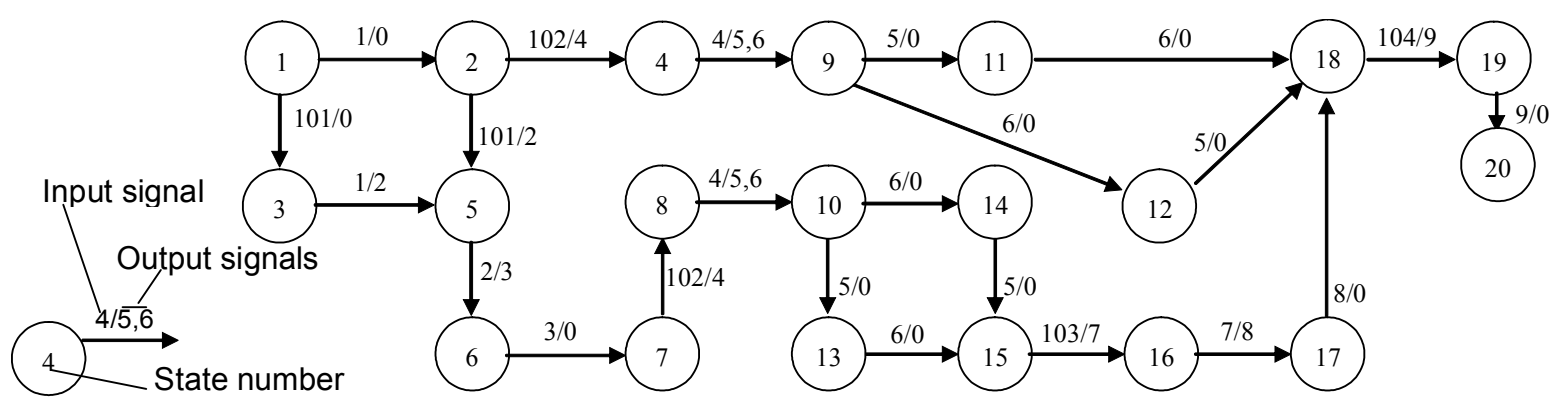

Fig. 2. The FSA transition graph for simulating the technologic process of servicing a group of local cars in the reception yard

The automatic device states $1 . .20$ are assigned to the graph nodes, the possible transitions between them are assigned to the arcs. The graph arcs are marked with characters $x / z$. Here $x$ is an internal signal from the object on the completion of operation with the number $x(x=1 \ldots 9)$ or an external command from the DM $(x=101 \ldots 104)$, under which a transition presented by the arc is under realization, and $z$ is a number of operation that should be started in so doing.

The state 1 , which means that a group of local cars is beyond a reception yard, is initial; the state 20 , when the cars of this group are directed to marshaling tracks, is final.

An automaton provides two options for servic- ing the group: with or without cutaway of shunting locomotive at technical inspection of cars. Selecting the service option is to be provided by the DM, who can issue a command 101 or 102 in the state 2, whereas commands 103, 104 enable the DP to manage the queues for breaking up of set of cars.

The FSA transition graph shown in Fig. 2 is the basis for formalization of TP for servicing the object in the FSM (see Fig. 3). In this case, the lists of identifiers of the operations executed, occupied executors and/or ones executing an operation and available commands issued by the DP are assigned to each state of an automaton. The executors in this case are: the reception track - RT, shunting locomotive - SL, yardman - YM, operator of car in- 
spection station - OP, team of car inspectors $-\mathrm{CI}, \quad$ team of commercial inspectors $-\mathrm{KI}$, hump $-\mathrm{H}$.

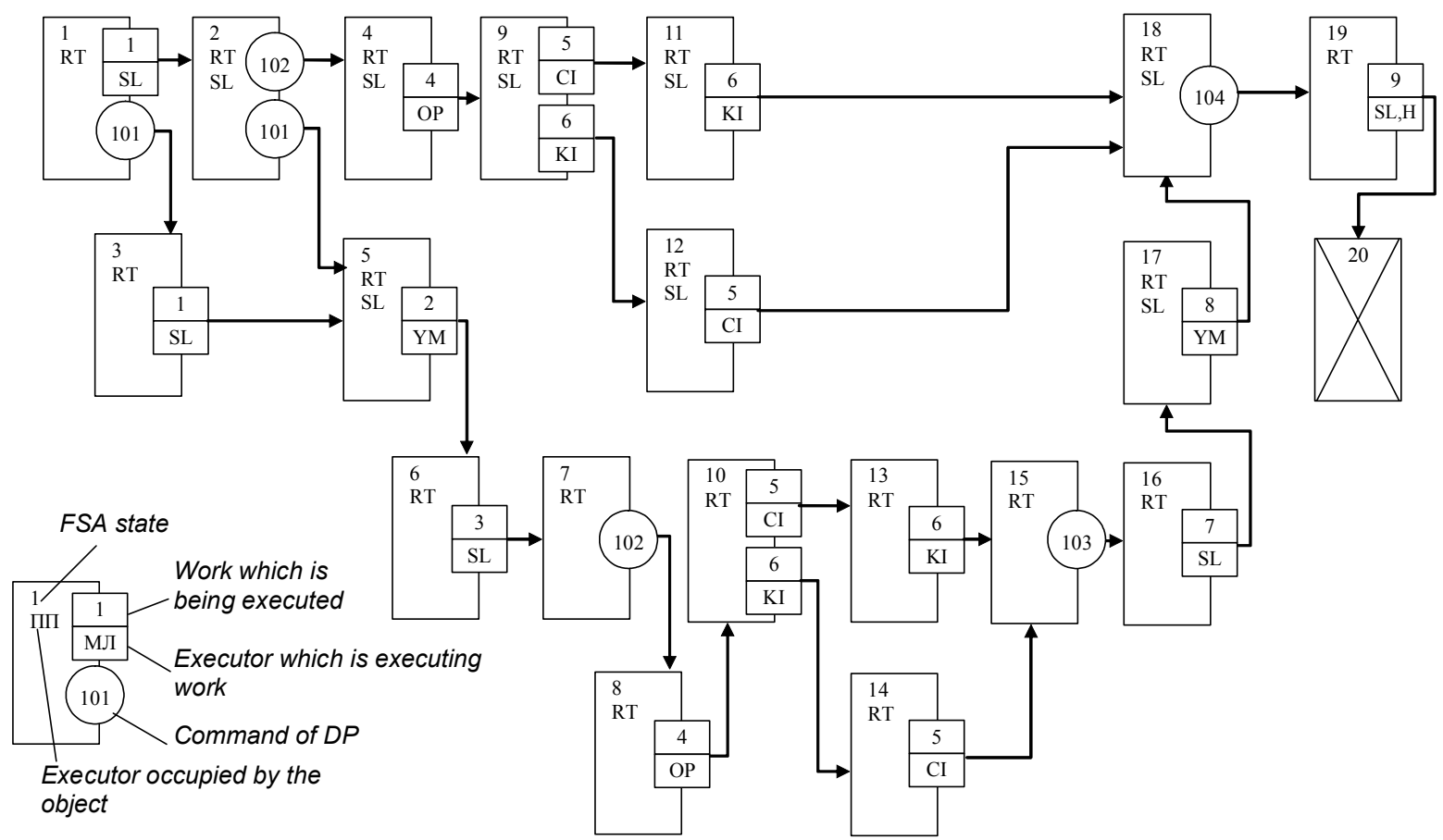

Fig. 3. Fragment of the technologic process of servicing local cars in the reception yard

To automate the construction of FSA's simulating the technologic processes in servicing objects of different categories at station, a special software editor is developed. The mentioned editor enables one to making interactively the required FSA transition graph from the standard elements and commands. The editor window and a fragment of graph constructed with its help is presented in Fig. 4.

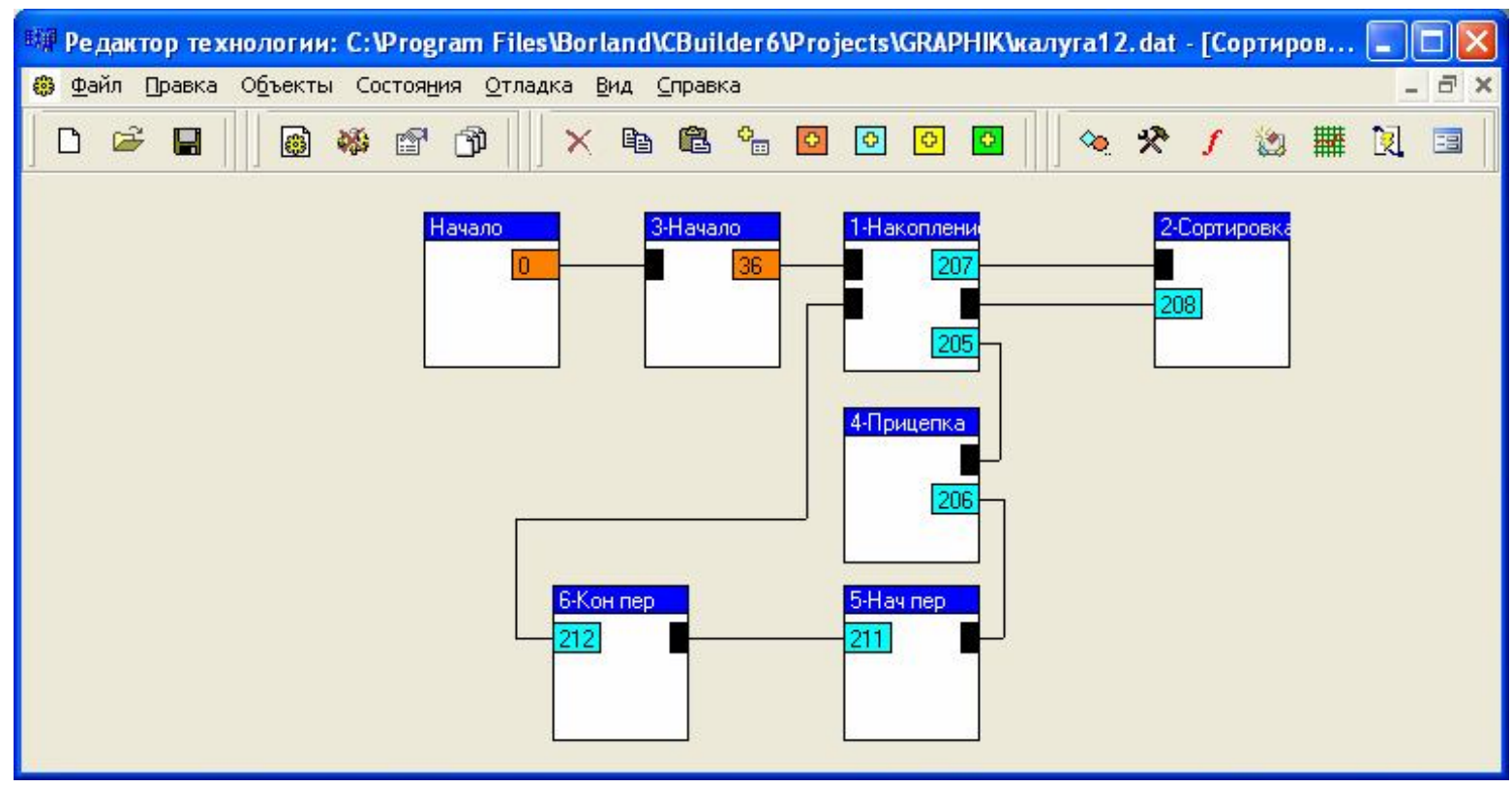

Fig. 4. Editor window of the technologic process of station operation

The technique developed allows simulating the station TP at any level of complexity and with any degree of detail. In doing so, the use of FSA's allows simulating various options of servicing the objects, which provides the significant flexibility in the model. Furthermore, the formalization of TP in the FSA form allows the interactive human participation in the process of simulating the station operation, and it allows simulating his/her interaction with the performers of technologic operations.

Traditionally, a graphic model in the form of daily schedule is used for the analysis of the tech- 
nical equipment and operation technology of railway stations. This model has the large information capacity and provides the high rate of search of and access to the necessary information. The main drawbacks of traditional development methodologies for schedules are the low rate of constructing the graphic image and obtaining the station operation indices, the neglect of random nature of the duration of technologic operations, the complexity of replicating, archiving and transmitting the information. In this context, the simulation model developed is augmented with a module of automated construction of the daily schedule of station operation. The chart is constructed automatically during the simulation of station operation, and the final result is stored in a file format $\left\langle^{*}\right.$.dxf» supported by graphics packages AutoCAD and CorelDraw.

In so doing, the work performed by a station is displayed on the special grid in the form of various graphics primitives; each of them corresponds to a certain technologic operation (train acceptance, technical inspection, breaking up, locomotive motion, etc.). Based on the chart analysis, one can determine the load of station elements and its operating indices as well. A fragment of such a chart obtained by the simulation results for the station operation is presented in Fig. 5.

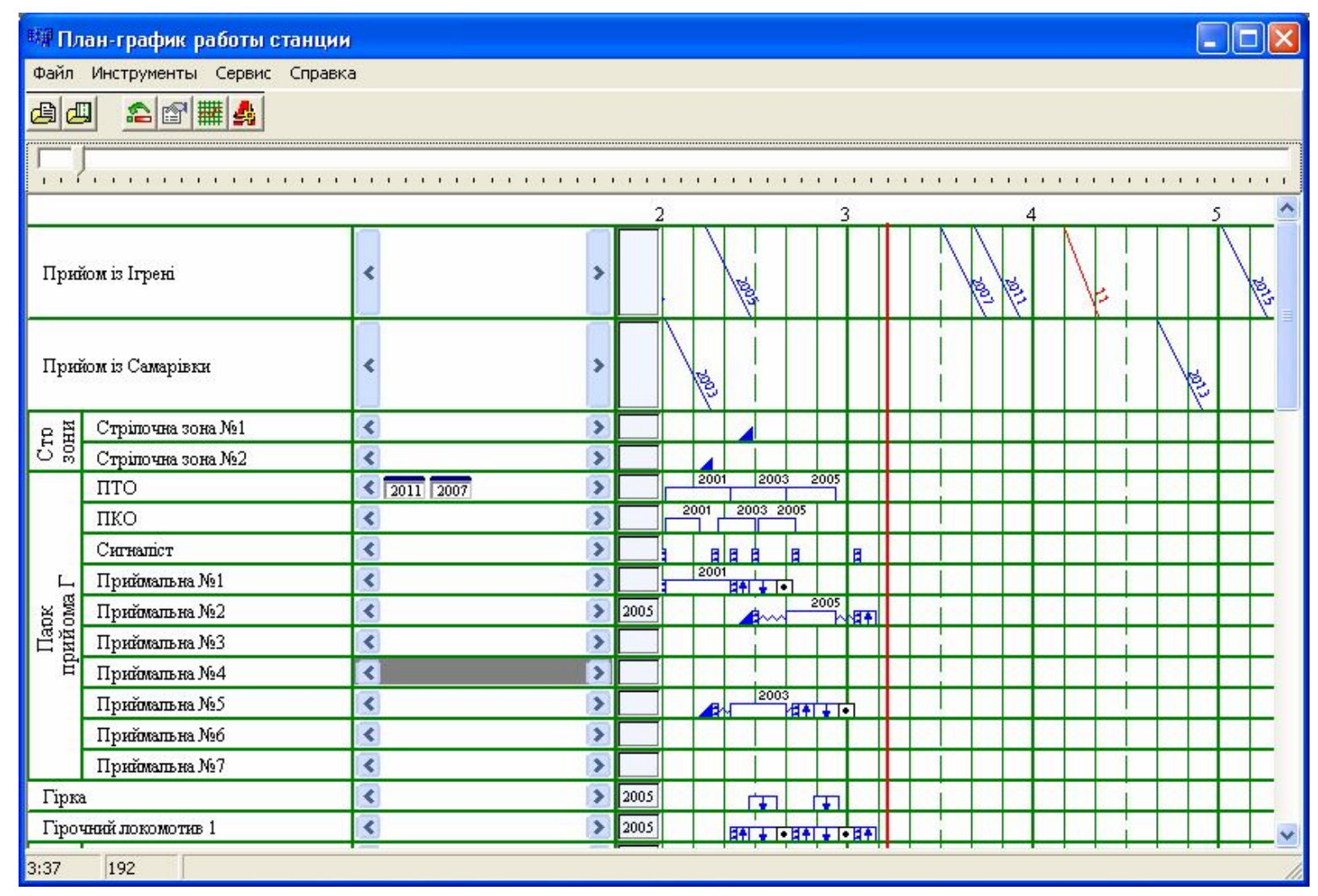

Fig. 5. Fragment of schedule of railway station operation

Approbation of the simulation technique suggested has been performed in the evaluation of design decisions on the reconstruction of a breakingup subsystem at one of the marshalling stations in Ukraine. To construct the ergatic model, a comprehensive survey of the station is performed; based on the related results, its technical equipment and technology process are formalized, the information model is developed, the parameters of the input stream of requests and time characteristics of performing the individual technologic operations are determined. Based on these data, the identification of model of breaking-up subsystem is completed. Evaluation of the model adequacy is exe- cuted on the basis of statistical analysis of random variables for staying time of trains in the system obtained at station as a result of chronometer observations and simulating the station operation. Testing the hypothesis of belonging these two samples to the same general set using the Wilcoxon test has confirmed the model adequacy. To get the technical and operational indices, characterizing the operation of breaking-up station subsystem, a series of simulation experiments with its model was carried out.

As an example, Table 1 shows the trend in the station operation indices with changing the number of reception tracks and the traffic volumes $N_{\mathrm{p}}$. 
Technical and operational performance of the station

\begin{tabular}{c|c|c|c|c|c}
\hline \multirow{2}{*}{ Index } & Quantity of & \multicolumn{4}{|c}{ Average daily number of trains } \\
\cline { 3 - 6 } & tracks & 10 & 20 & 30 & 40 \\
\hline \multirow{2}{*}{$\begin{array}{c}\text { Average waiting time for a train to } \\
\text { arrive, [min] }\end{array}$} & 4 & 0,18 & 0,7 & 3,1 & 9,4 \\
\cline { 2 - 6 } & 5 & 0,18 & 0,2 & 0,18 & 0,3 \\
\hline $\begin{array}{c}\text { Average waiting time for a train at the } \\
\text { yard, [min] }\end{array}$ & 4 & 68,7 & 72,4 & 83,4 & 125,6 \\
\cline { 2 - 6 } & 5 & 68,6 & 70,4 & 77,46 & 105,3 \\
\hline $\begin{array}{c}\text { Average waiting time for a train loc } \\
\text { motive at the yard, [min] }\end{array}$ & 4 & 5,2 & 5,3 & 5,6 & 6,4
\end{tabular}

The results obtained are used in a feasibility comparison of the reconstruction variants developed and allow one making operative informed decisions on appropriate changes in technical equipment of the park with changes in workload.

Thus, the practical implementation of the developed concept of ergatic simulation has confirmed its sufficient high efficacy in both the integrated assessment of options of the design decisions for improving the railway stations' operation. Also the development of computer simulators for training and testing the station duty officers is one of effective directions of using the ergatic simulation. In this case, a powerful ergatic model of relevant railway station is a basis for each computerbased simulator of such a kind. Currently the software-and-hardware tools, which greatly simplify and activate the replication of such models and computer simulators for various stations, are developed. The creation of such a complex of models should address a wide range of applications aimed at improving the operation of railway stations

\section{REFERENCES}

1. Персианов, В. Моделирование транспортных систем [Текст] / В. Персианов, К. Скалов - М.: Транспорт, 1972. - 208 p. [In Russian: Persianov, V. \& Skalov, K. Modeling of the transport systems. Moscow: Transport].

2. Лещинский, Е. Имитационное моделирование на железнодорожном транспорте [Текст] / Е. Лещинский - М.: Транспорт, 1977. - 176 p. [In Russian: Leschinkiy, Y. Simulation modeling on the railway transport. Moscow: Transport].

3. Нагорный, Е. Моделирование функционирования комплекса «Сортировочная станция - прилегающие участки» с помощью сетей Петри [Текст] / Е. Нагорный, Е. Алешинский // Информационноуправляющие системы на железнодорожном транспорте. - 2000. - № 2. - P. 98-103. [In Russian: Nagorniy, Y \& Aleshinskiy, Y Modeling of complex functioning "Marshalling Yard - adjacent areas" with Petri nets. Information-controlling Systems on the Railway Tran port].

4. Giua, A. \& Seatzu, C. Modeling and supervisory control of railway networks using Petri nets. IEEE Tr

ns. on Automation Science and Engineering. - 2008. Vol. 5. - № 3. - P. 431-445.

5. Milinkovic, S. \& Markovic, S. \& Veskovic, M. \& et al. A fuzzy Petri net model to estimate train delays. Simulation Modelling Practice and Theory. - 2013. № 33. - P. 144-157.

6. Szücs, G. Railway Simulation with the CASS NDRA Simulation System. Journal of Computing and Information Technology. - 2001. - Vol. 9. - № 2. - P. 133-142.

7. Сукач, Е. Стенд имитационного моделирования сортировочной станции железнодорожной сети [Текст] / Е. Сукач // Проблемы программирования. 2009. - № 3. - P. 81-89. [In Russian: Sukach, Y. The stand for simulation modeling of marshalling yard on railway network. Programming problems].

8. Бобровський, В. Базова модель колійного розвитку в імітаційних моделях залізничних станцій [Текст] / В. Бобровський, Д. Козаченко, Р. Вернигоpa // Зб. Наук. праць Української держ. акад. зал. трту. - 2004. - № 62. - P. 20-25. [In Ukrainian: Bobrovskiy, V. \& Kozachenko, D. \& Vernigora, R. The basic track model in the simulation models of railway stations. Collection of Scientific Papers of the Ukrainian State Academy of Railway Transport].

9. Вернигора, Р. Моделирование работы систем станционной автоматики в эргатических имитационных моделях железнодорожных станций [Текст] / Р. Вернигора, В. Малашкин // Сб. науч. трудов Днепропетр. нац. ун-та ж.д. тр-та «Транспортные системы и технологии перевозок». - 2011. - № 2. - Р. 3137. [In Russian: Vernigora, R. \& Malashkin, V. Modeling of the railway automation systems in the ergatic models of railway stations. Collection of Scientific Pa ers of the Dnipropetrovsk National University of Rail ay Transport «Transport systems and transportation te hnologies»].

10. Бобровский, В. Функциональное моделирование железнодорожных станций в тренажерах оперативно-диспетчерского персонала [Текст] / В. Бобровский, Р. Вернигора // Математическое моделирование. - 2000. - № 2(5). - P. 68-71. [In Russian: Bobrovskiy, V. \& Vernigora, R. Functional simulation of railway stations in the simulators for dispatching personnel. Mathematic modelling].

Надійшла до редакції 14.10.2013.

Прийнята до друку 15.10.2013. 